\title{
Miranda
}

Revue pluridisciplinaire du monde anglophone /

Multidisciplinary peer-reviewed journal on the English-

speaking world

4 | 2011

Samuel Beckett : Drama as philosophical endgame?

\section{Beckett, Wittgenstein and Blanchot: Language Games from Text to Theatre}

\section{Katy Masuga}

\section{CpenEdition}

\section{Journals}

\section{Electronic version}

URL: http://journals.openedition.org/miranda/1981

DOI: 10.4000/miranda.1981

ISSN: 2108-6559

Publisher

Université Toulouse - Jean Jaurès

\section{Electronic reference}

Katy Masuga, "Beckett, Wittgenstein and Blanchot: Language Games from Text to Theatre", Miranda [Online], 4 | 2011, Online since 24 June 2011, connection on 16 February 2021. URL: http:// journals.openedition.org/miranda/1981 ; DOI: https://doi.org/10.4000/miranda.1981

This text was automatically generated on 16 February 2021.

\section{cc) (i) () $\Theta$}

Miranda is licensed under a Creative Commons Attribution-NonCommercial-NoDerivatives 4.0 International License. 


\title{
Beckett, Wittgenstein and Blanchot: Language Games from Text to Theatre
}

\author{
Katy Masuga
}

1 As often noted by critics, Mercier et Camier, written in 1946 but not published until 1974, in many ways foreshadows En attendant Godot (1953) and includes stylistic elements later found in the trilogy (Molloy 1951, Malone meurt 1951, L'innommable 1953). The parallels include, for example, the novel's expression of futility of movement and action, the curiousness of the characters' vanishing and useless possessions and a narrative voice that hides, in Curtis Willits' words, the "imageless image" of the space of the text ("The Blanchot/Beckett Correspondence" 259). Seemingly coinciding with Beckett's so-called revelation in 1945 that affected his perception of the world and the style of his body of work to come (an idealistically questionable but still relevant event), characterized in Krapp's Last Tape (1958, La Dernière Bande 1959), Mercier et Camier, Beckett's first major work in French, serves as his primary radical expression of language play and the significance of the concept of silence, in a manner that unknowingly parallels Wittgenstein and Blanchot's contemporaneous philosophy on the uses and abuses of language.

2 Under consideration in this analysis is Beckett's exploitation of the destabilizing potential of a form of theatre that implies the impossibility of full or complete expression. The first of three main points of this article draws a parallel between Mercier et Camier and Godot showing how both texts establish a rapport between the characters and the audience (reader or viewer) that is based on an incompleteness of expressed language. The second point suggests that Beckett uses language games in a manner similar to what Wittgenstein and Blanchot discuss in their work in order to produce this effect. Finally, the third point considers Godot as the welcome manifestation of what Beckett first began in Mercier et Camier, but which also gives him the opportunity to produce a greater effect upon the audience by using the space of the theatre as live performance. 
The late 1940s generally marks a shift in Beckett's writing, where, notably, he begins to produce highly condensed works that provide stark and defining images of the human condition, which, in a profoundly implicit manner, not only fundamentally point toward a playfulness in futility but that also place a forceful emphasis on language as an inherently useless tool for meaningful expression in metaphysics. It is significant to note, however, that this claim appears to imply that language is an altogether useless tool, when indeed the contrary is the case. Beckett undermines the basic functioning of language for the very sake of its possibility. Like Wittgenstein and Blanchot, Beckett demonstrates an acute aware of the effects of metaphysical inquiry and in exploiting this gaping, yet often overlooked, hole in language. It is as though the recognition and acceptance of the flexibility and fallibility of language is itself a revelation (and possibly a disappointing, or at least destabilizing, and also humorous one), based on the given assumption that language can in some way provide universal or meaningful truths about the world.

In a letter to Axel Kaun dated July 9, 1937, Beckett explains:

Ein Loch nach dem andern in [der Sprache] zu bohren, bis das Dahinterkauernde, sei es etwas oder nichts, durchzusickern anfängt-ich kann mir für den heutigen Schriftsteller kein höheres Ziel vorstellen. (514)

To drill one hole after another into [language] until what is cowering behind, be it something or nothing, begins to leak out-I cannot imagine a greater goal for today's writer. (My translation)

Beckett wants to reveal our presumptions about language and to stretch the limits of what language can do in a literary context. He begins serious exploration of this pursuit in prose, in Watt and Malloy but also in Mercier et Camier, and eventually finds its most lucrative expression in the theatre.

6 In Mercier et Camier, for instance, the "summary" included after each set of two chapters manages to reduce the already reductive chapters themselves into focused articulations of the events that occur, thus seemingly stripping out even further any possible interpretive or analytical meaning from the text. The summary of the final chapter (twelve in French and eight in English, as the summaries in the French version are labeled as independent chapters) reads as follows:

La vie de survie.

Camier seul.

Mercier et Watt.

Mercier, Camier et Watt.

Le dernier agent.

Le dernier bar.

Mercier et Camier.

Le pont de l'Ecluse.

Mercier seul.

L'ombre se parfait. (211-212)

The life of afterlife.

Camier alone.

Mercier and Watt.

Mercier, Camier and Watt.

The last policeman.

The last bar.

Mercier and Camier.

Lock Bridge.

The arctic flowers. 
Mercier alone.

Dark at its full. (101)

The chapters in Mercier et Camier are not divided, allowing the divisions that the chapter summaries provide to appear meaningful or to have an actual, overtly evident purpose (as though the summaries are anticipated by the reader). The reader, however, must then randomly insert mental breaks where the text turns to the next topic, as indicated in the summary, and to retroactively understand the text in light of these newly presented divisions.

The final chapter begins with Mercier and Camier having just parted. The first quarter of the chapter has no characters but is the narrative voice speaking of the general routine of a day and the inherent fatigue of life and its meaningless routines. The reader is then informed, in the summary at the end, that this description is "the life of afterlife", thus connecting the summary directly with the wording in the chapter itself. Similarly, the first sentence of the short final paragraph of this last chapter is the following: "Seul il regarda son ciel s'éteindre, l'ombre se parfaire" (210). ("Alone he watched the sky go out, dark deepened to its full" [100]). In some instances the connection is evident, as in this one ("dark at its full" and "dark deepened to its full"), but in others it is made through an inference that the narration forces the reader to take.

The summary design of listing the "results" of preceding chapters by number also demonstrates how Beckett uses language to engage the reader with the words as though they are not part of a story but are merely providing objective details. However, these "details" are meaningless and can themselves be considered to be what Beckett calls "that something itself"-a phrase used in "Dante ... Bruno. Vico ... Joyce" (1929) to describe Joyce's writing: "His writing is not about something; it is that something itself" (14). Such texts as Joyce's (according to Beckett) and Mercier et Camier (according to the present argument) are not describing an idea within the context of the text but are declaring the text itself as that idea. In A Reader's Guide to Samuel Beckett (1973) Hugh Kenner writes: "The difficulties, which are not to be underrated, occur between the sentences, or between the speeches" (10). Already in Mercier et Camier Beckett withholds from the reader the idea of anything more to the text than its literal presence.

10 By reducing, for example, the passages on the everyday at the beginning of the last chapter to the phrase "the life of afterlife", any possibility of the text actually being about "the life of the afterlife" is removed. Instead, the text is immediately about the reduction of the text to a summary, rendering both the text and the summary meaningless in any traditional sense. What is instead revealed-or touched upon-is the presence of the words and the peculiar relation between the passages in the text and their summaries, putting the reader in the awkward position of trying to reconcile this unexpected arrangement of the text.

11 It is clear enough that Beckett's later work enacts as opposed to describes, but Mercier et Camier already works in part toward this effect in passages, which is particularly evident in the chapter summaries, even pointing toward a narratorless speech that reflects the profound "something itself"-the writing is no longer descriptive or explanatory but becomes creation itself, with a concentration not on any subject matter but specifically on the writing. The following exchange between the two title characters from Mercier et Camier also illustrates. 
Après un moment de silence Camier dit :

Si on s'assoyait, cela m'a vidé.

Tu veux dire s'asseyait, dit Mercier.

Je veux dire s'assoyait, dit Camier.

Assoyons-nous, dit Mercier. (15)

After a moment of silence Camier said:

Let us sit us down, I feel all sucked off.

You mean sit down, said Mercier.

I mean sit us down, said Camier.

Then let us sit us down, said Mercier. (7)

The humor of this passage is directly related to a use of language that is both about the possibility of latent meanings and also not at all about meaning whatsoever. The reader can first laugh at Camier's interpretation of the vernacular, but his deadpan insistence on such an his interpretation simultaneously raises questions for the reader as to other possible meanings-indeed, including a more conventional one. In this passage Beckett also demonstrates the very possibility of such an exchange and of Camier's actually meaning something that he perhaps shouldn't mean. Mercier's direct and perhaps even confident concession deflates the reader's possible irritation with the seeming senselessness of the exchange. That is to say, despite the exchange being apparently without tremendous meaning, it is presented not only as highly meaningful but rather as concise, direct and matter-of-fact. The passage is strikingly similar to the exchange at the end of Godot:

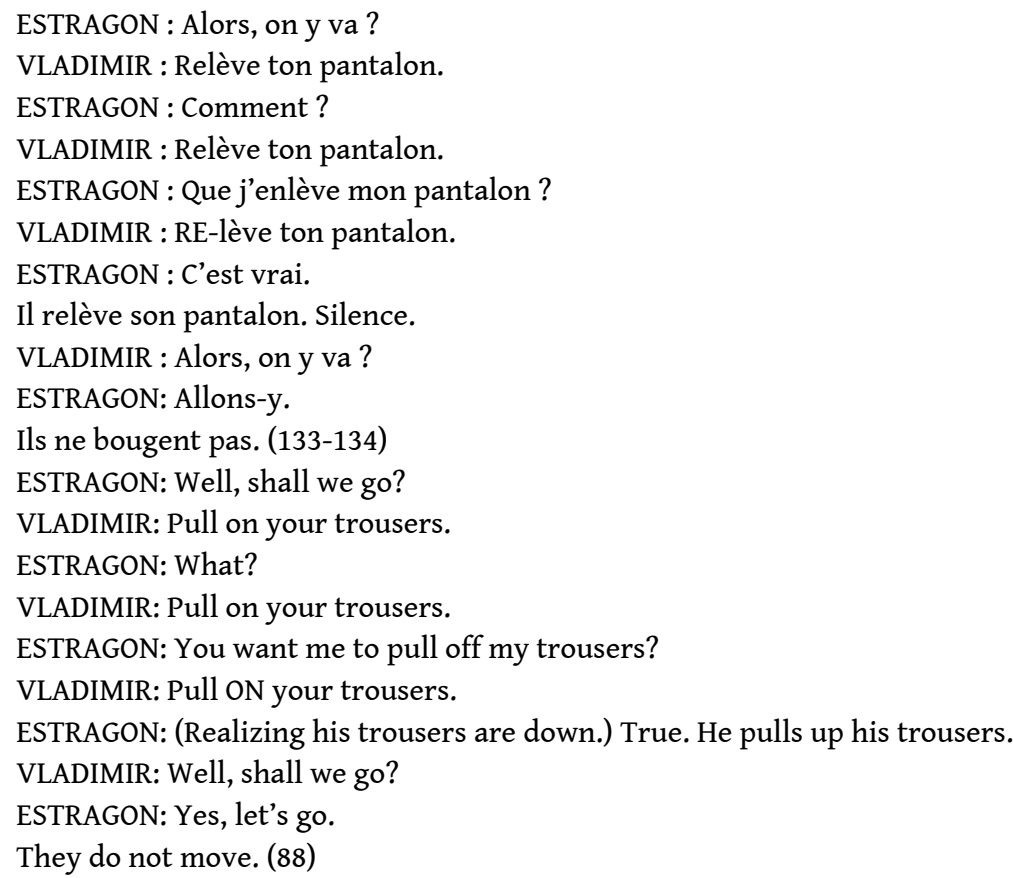

13 As with the above passage from Mercier et Camier, the emphasis is not on the action (or the non-action) but on the lack of obvious connection between the use of the words and what they otherwise represent. The viewer is not only humored by Estragon's obliviousness but also surprised by his subsequently peculiar response ("C'est vrai", "True"), which is, curiously, a precise yet slightly inaccurate response within the context. Furthermore, as in Mercier et Camier, "true" is not only taken as the proper response, but it is also followed by an incomplete concession. ("Shall we go? Yes, let's go. They do not move.") Once again, the reader's attention is drawn to the language insofar as it highlights the characters' casual acceptance of their own odd behavior 
(e.g., to consider with earnestness pulling off one's trousers, to not move when announcing movement).

Despite drawing the attention of Blanchot and other contemporary theorists including Bataille, Lacan and Adorno, one contemporary of Beckett's whose ideas are intimately related but with whom Beckett apparently never directly crossed paths, is Wittgenstein. Sounding peculiarly similar to Mercier et Camier and even more to Godot, the last of the seven tenets of Wittgenstein's Tractatus (1921) reads: "Wovon man nicht sprechen kann, darüber muss man schweigen." ("Of that which one is unable to speak, one must pass over in silence" My translation). Investigating the inherent absurdity in metaphysical philosophizing, Wittgenstein comes to insist on the necessity of reticence -by way of schweigen-to avoid mistakes in philosophy when confronted with the limits of language. In the late 1930s after a lengthy period of silence of his own, Wittgenstein develops this concept at length in the Philosophische Untersuchungen (Philosophical Investigations, posthumous 1953), with which Beckett would have been familiar only later on, stating in a 1961 letter to John Fletcher that he had just very recently read Wittgenstein (Perloff 134).

Schweigen is only awkwardly translated in either English or French (slightly less so in French, with the reflexive verb se taire), as it simultaneously contains within it a sense of remaining silent but also the overt activity of being silent and of enacting a state of silence-an active doing that is also a non-doing (an action that is itself a deliberate non-action). In Mercier et Camier, Beckett begins to express more visibly a similar theory through a style of writing that progressively seeks to enact the fundamental structure of schweigen, and which leads him finally to turn to the theatre to perform this paradoxical communication of silence, exposing our dependency on language despite its stupefying limits. Generally speaking, Wittgenstein suggests that our sophisticated, yet perpetually inadequate, metaphysical reasoning is not due to lack of clarity or logical insight but to the misuse of language.

With an emphasis on the humour in paradox, Wittgenstein's language games and Blanchot's theory on the role of silence in the literary work are both significant to Beckett's shift to the theatre. For, despite the possibility of reading Beckett as a nihilist or even as a negative, anti-literature author, it is important to note the tremendous longevity and deeply communicative nature of his writing career. Beckett never ceased writing, attesting to the value he placed not only on art in general and on his craft in particular, but also on language itself and the power of the word. The question is, then, how can Beckett's critics reconcile his apparent love of writing with the content of writing that seems to suggest, if not the opposite, at least a focus on the incredible struggle to continue? In setting Beckett in relation to Wittgenstein and Blanchot, the reader can recognize Beckett's insistence on an optimistic playfulness in language but a playfulness that directly concerns the seemingly lacking nature, or lacking possibilities, in the expression of language.

In Wittgenstein's Ladder (1996) Marjorie Perloff includes a chapter on reading Watt through a Wittgensteinian lens, pointing out that most analyses of Watt focus on "the 'Beckett' constructed in the Paris of the fifties," namely, "the chronicler of a postwar, postatomic world of alienation, emptiness and inevitable despair" (116). Perloff instead insists upon a reading that focuses on Beckett's interest in language and in the similarity of his prose as reflective of Wittgenstein's philosophy. She also mentions Jacqueline Hoefer's essay "Watt," which, already in 1959, suggests the possibility that 
Beckett is referring in Watt to Wittgenstein's famous ladder metaphor in the Tractatus that represents the understanding of language as a (fallible) tool and nothing but. Wittgenstein claims: "Er muss sozusagen die Leiter wegwerfen, nachdem er auf ihr hinaufgestiegen ist" (\$6.54). ("He must so to speak throw away the ladder, after he has climbed up on it.") Beckett inserts a curious twist in Watt that has the potential to be read in a manner consistent with his interest in deliberately misusing language, which Hoefer contends is directly in alignment with Wittgenstein. The precise passage from Watt is as follows: "What was changed was existence off the ladder. Do not come down the ladder, Ifor, I haf taken it away" (42). Beckett, however, completely denies the reference to Wittgenstein, claiming his ladder is a reference in an old Irish song. Perloff denounces Hoefer's analysis that the curious terms "Ifor" and "I haf" respectively refer to a type of ladder and a literary rendering of "I have" with a German accent. The denouncement is not necessarily based on Hoefer's grammatical conclusions but on her misunderstanding of Wittgenstein: it is not a matter of constructing a system to be mastered and its methodology to subsequently be thrown away (the ladder), but rather of acknowledging that no such system exists in the first place, revealed through a series of steps that themselves become useless once this observation is made.

Although Perloff disputes Hoefer's analysis, the investigation into an effective link between Beckett and Wittgenstein is well established and remains highly relevant. Perloff's personal assessment is that whether or not Beckett is directly referring to Wittgenstein, the writers share an affinity in outlook, which is neither metaphysical nor pessimistic. E. M. Cioran makes the following remark in 1976 of Wittgenstein:

More than once I have found common traits in him and in Beckett. Two mysterious apparitions, two phenomena that please one by being so baffling, so inscrutable. In both, one and the other, the same distance from beings and things, the same inflexibility, the same temptation to silence, to a final repudiation of words, the same desire to collide with boundaries never sensed before. (Critical Heritage 379)

In response to the manner in which Beckett's work changed how we understand the potential of literary language, Deleuze writes in Cinéma I (1983): "Comment nous défaire de nous-mêmes, et nous défaire nous-mêmes?" (97). ("How can we rid ourselves of ourselves, and demolish ourselves?" [Cinema I 66]). By drawing attention to gaps in reasoning, Beckett reveals the senselessness in using language to philosophize in a manner that disregards les règles du jeu and that subsequently leads to the production of incomprehensible metaphysical conclusions. Wittgenstein frequently points out that reasoning errs when it attempts to express in language that which is only knowable beyond the sensical (things that can only be shown). What is "unsayable", then, are the ideas evolving from such areas of thought as metaphysics, ethics and aesthetics. Beckett draws out the humor in such mistakes in reasoning, creating interactions where his characters are often just as disillusioned and confounded by the apparent shortcomings of language-thus transferring that deficiency onto the world itself, producing this existential gap in meaning, yet making its obvious connection to (and dependence upon) language most evident.

In "The Prose of Samuel Beckett: Notes from the Terminal Ward" James Atlas writes: “Beckett verifies Wittgenstein's claim: 'Nothing is lost if one does not seek to say the unsayable. Instead, that which cannot be spoken is-unspeakably-contained in that which is said!" (192). What Beckett reveals by writing nonsense is the "nothing" that has no quality within language. It cannot be articulated because it is in the realm of the unsayable even though it is being said. No articulation can be made about what is 
"nothing", because, according to Atlas, "to state what is 'unsayable' is to invent reality rather than elicit its character" (192). Thus, to state what is unsayable is to create metaphysical truths where, of course, none existence. Beckett aims toward the limits of language, not toward meaning. He pushes toward the unsayable, exposing not just the untruth in metaphysical inquiry but the strange pleasure in the paradox of connecting language in unusual ways. Straining to say the unsayable reveals perhaps comical emptiness, but only in the sense that it is revealing a vacancy that immediately fills itself with the meaning of the complicated concept of "nothing" in its revelation.

Searching in vain, then, for a means to comprehend the text through conventional measures, the reader is left facing a use of language that constantly defies standard expectations, ironically through its casual and often humorous form. In the case of Mercier et Camier the emphasis is on idiomatic speech, and particularly the French idiom from the position of a non-native speaker-a technique Beckett later perfects in Godot. This device draws the reader's attention to the fact that the narrator is examining each word as it is written and is hence focusing not on anticipated meaning but on the staging itself. In the second chapter just before the summary, Mercier and Camier encounter two children. As they call out "Papa!" the response is the following: "Bonsoir, mes enfants, dit Mercier, maintenant allez-vous-en" (47). What occurs next in the text is an unexpected comment by the narrator: "Mais ils ne s'en allèrent point" (47). ("'Good evening, my children, said Mercier, get along with you now.' But they did not get along with them, no..." [23]). Beckett often refuses to allow expressions to go unnoticed as the curious alterations in conventional and rule-regulated language that they are. In the first instance, Mercier uses the reflexive pronoun in the French (and a prepositional phrase with pronoun in English) to give his command force: "vous" ("with you"). Because of its grammatical presence in the command, this reflection (of the command: you do this ["go"] with yourself) is kept in the narrator's response, but which then has a literal and thus humorous (and possibly destabilizing) effect: in the narrator's comment, the presence of the reflexive quality is superfluous but not exactly ungrammatical, making for an uncertain explanation (with various interpretations) of what has just occurred. What further complicates this passage is that this statement is made by the narrator, thus estranging the reader even further from a more comprehensive connection to the world of the text. It seems Beckett remains resolute in leaving the reader in the awkward position of not knowing any "full" purpose of such nuances while fully knowing them through the necessarily complete and haunting state of incompletion (or perhaps unclarity) of which they are composed.

As each example demonstrates, Beckett does not invent, that is to say, he does not provide stories for the sake of stories but instead for the sake of showing the possibility of peculiar and even entertaining gaps in language. Beckett draws the reader and viewer's attention to a universal and profound dependency upon language and upon the idea that language will always necessarily behave as expected. However, Beckett is also focusing on the ways in which we expect language to behave even when it is contrary to the language game at hand. Such exercises in his work, then, that are often interpreted through the concept of nonsense, must also be rethought within their own context. The reader or viewer must ask what this disconnection between performance and language suggests about this universal blind dependency on language. Beckett seems to ask his reader or viewer to be wary, not only of the codifications imposed upon us by language (as Michael Worton suggests in "Waiting for Godot and Endgame: theatre as text", for example) but also of making assumptions about the possibilities of 
language. This idea returns the analysis back to Wittgenstein's insistence of language games as tools for avoiding mistakes in reasoning-mistakes in language that result in abstruse metaphysical dilemmas. Indeed, these dilemmas can even include those readings of Beckett that assume interpretations of the absurd, existential, symbolic, and so on.

Kenner explains that in reading Beckett "we shall experience the wreckage the story has left" (9). The language games that Beckett undertakes are like something from a Marx Brothers film: "Je sens l'humidité qui me rentre dans la raie, dit Camier. Du moment qu'il n'en sort pas, dit Mercier" (91). ("I feel the damp creeping up my crack, said Camier. So long as none creeps down, said Mercier" [46]). Although the "joke" is slightly different in the French and English, the effect is quite the same. Two items are at work: instead of understanding Camier's metaphorical language use, and that is to say, its conventional use ("to creep up"), Mercier instead interprets it literally. The second point, however, is informed by the first: Mercier is not understanding Camier's metaphorical language. In fact, for the joke to take place, the reader would assume that Mercier must in fact understand Camier's metaphorical language but deliberately chooses to respond literally.

What this passage demonstrates is once again the play that ensues when language is torqued beyond its obvious use. We expect Mercier to respond to the metaphorical meaning, since we are aware of the language game that is taking place. When he does not respond in this way, we are surprised at the text for violating this convention, and we are also subsequently made aware of language's imposed limitations as well as its new possibilities. Beckett makes it clear that the joke is actually on the reader, since it is only the reader who is aware of what is seen on the page, and it is also the reader who must accept the text at face value. In this instance, Mercier both does and does not "understand" Camier's statement, but all that can be assumed by the reader is that Camier and Mercier are simply not exactly participating in the same language game. Or, rather, their subtle misunderstanding produces a different effect from the expected effect of the language game set out by Camier's original claim. (And, even then, it is not really as though a "misunderstanding" exists at all, as it seems Mercier and Camier communicate in a manner that both seem to accept and understand.)

Wittgenstein explores these kinds of issues in language and language games throughout his work. In Über Gewissheit (1969 posthumous, On Certainty), for example, Wittgenstein plainly unravels G. E. Moore's argument from "Proof of an External World" (1939), in which Moore describes holding out his hand and declaring that, because he knows of the existence of his hand by looking at it in front of him, he knows as plainly the existence of the external world. Wittgenstein points out, however, that such an argument is tantamount to Descartes' metaphysical inquiry of the existence of God in Discours de la méthode (1637). As Wittgenstein explains, these are arguments that are misled by an understanding that language can do more than show empirical propositions; and, as such, they attempt to show the logical foundations of those propositions and in an empirical manner. This undertaking is an impossibility, since any act of doubt already rests upon a judgment that a priori indicates doubt is not only permissible but necessary to evaluate knowledge. Wittgenstein writes: "Die Wahrheiten, von denen Moore sagt, er wisse sie, sine solche, die, beiläufig gesprochen, wir Alle wissen, wenn er sie weiß" (\$100) ("The truths which Moore says he knows, are such as, roughly speaking, all of us know, if he knows them"). A distinction exists 
between saying and showing, such that certain types of propositions (empirical) can actually say things about the world, whereas others (logical) can only show them, since it is these latter that inherently and necessarily serve as presupposed principles for understanding. Where they end is where schweigen begins.

As in direct response to Moore, Über Gewissheit begins with Wittgenstein declaring: "Wenn du weißt, daß hier eine Hand ist, so geben wir dir alles übrige zu" (\$1) ("If you know that here is one hand, we'll grant you all the rest"). Thus, knowing that there is a hand is not something that can be proven or explained. It simply is, and using language correctly, that is to say productively, is to understand that one's knowledge of this hand is not tied up with being able to prove the claim of its existence. However, it is the nature of metaphysical inquiry to raise doubts, and thus even propositions that logically cannot be doubted indeed become doubted. This undertaking results in effects that are both disturbing and humorous (e.g., Descartes' dubious evil spirit in the former, Beckett's challenging fiction in the latter). The following exchange between Mercier and Camier is the epitome: "As-tu envie de chanter? dit Camier. Pas à ma connaissance, dit Mercier" (36) ("Do you feel like singing? said Camier. Not to my knowledge, said Mercier" [18]). Mimicking (and mocking) weighty epistemological dialectics, Beckett draws attention to the absurdity in violating what Wittgenstein here explains very simply: "Wohl aber läßt sich fragen, ob man dies sinnvoll bezweifeln kann" (\$2). ("What we can ask is whether it can make sense to doubt it".) Because it can't and doesn't make sense to doubt one's own feeling about an interest in singing or not, the passage successfully highlights this dual nature in language between empirical proof and logical form but in a way that is both awkwardly funny and disconcerting.

Beckett's work can also be contextualized in relation to understanding how the theatre serves as a more viable creative space for enacting the paradoxical quality of communicative expression through silence. Dissatisfied with the early prose work of Mercier et Camier, Beckett deliberately did not publish it until much later and, even then, reluctantly. Despite what appears to be evidence in his letters of what he was attempting with Mercier et Camier, this delay suggests that Beckett did not satisfactorily achieve the desired literary effect-what he called: "Literatur des Unworts" ("German Letter to Kaun, 9 July, 1937" 514) ("Literature of the unword" My translation). However, Beckett clearly found that strategy with Godot via a means more capable of demonstrating the existential issues of the impossibilities of language. In Mercier et Camier the relation is between the characters and the text. In Godot, it is between the viewer and the characters, but they achieve the same effect: both draw the reader and viewer into the unexpected and uncomfortable space where the words no longer stand for what they typically have stood for and hence into a distancing and questioning of meaning.

On a visit to Dublin from Paris in 1945, Beckett supposedly concluded that his literary interests should no longer be directed toward trying to gain more about the world and the attempt to render that in words, as he perceived to be his inherited pursuit from Joyce. His new pursuit would instead be to accept the inherent impoverishment of words and, thus, use his creative forces to subtract from the world and to negate the assumptions about it. In Damned to Fame: The Life of Samuel Beckett (1996), James Knowlson de-dramatizes the revelatory significance generally given to this event in popular culture but acknowledges, in any case, that a notable shift did take place in Beckett's style of writing at this time, but that it should be attributed to multiple 
elements including World War II, Beckett's life-threatening stab wound, his self-exile and his extensive psychotherapy treatment (320). In the brief essay "Normandy Landing" (2010), Phyllis Gaffney also notes in particular that Beckett's voluntary service at the emergency hospital in Saint Lô in Normandy greatly impacted his writing as well. After this time, Beckett's focus turned toward the portrayal of lack and the exploitation of this impoverishment through its very physical manifestation in the theatre, which is potentially better equipped for depicting life closer to how it really is: an actual unfolding of events in space and time.

These experiences of the mid-1940s led Beckett to pursue more strongly "the literature of the unword"-having first developed the concept in the mid-1930s. Beckett describes this needed change in full: "Die Sprache da am besten gebraucht wird, wo sie am tüchtigsten missgebraucht wird" (514). ("Language is used best where it is most efficiently misused" My translation.) Misusing language permits the hearer the opportunity to question the very concept of a correct or true form for meaning and comprehension. Such misuse, or perhaps unordinary use, opens up new avenues of thought and creates new possibilities for actualizing unanticipated effects that it can have on understanding. It was after this time that Beckett took up the theatre, which, as an active-living, as it were-depiction of the world, subsequently became for him a form necessarily able to depict the nuances that can manifest in the struggle to creatively manipulate language. By using a medium that displayed life unfolding, Beckett was able to make that displaying-the staging-itself a source for inquiry. The production could immediately present ambiguity of meaning where meaning was otherwise thought to be self-evident. The sequence of events on stage could suddenly become awkward, foreign, mechanically or arbitrarily joined and no longer be taken for granted as an inherently meaningful manifestation of a scenario extracted from life. Ultimately, the theatre could better show its own limitations as well as those of language in general.

To this end, Beckett's later works, such as Godot, most clearly toy with the approach of the "something itself", coinciding with Wittgenstein's same idea from the Philosophische Untersuchungen, where he writes: "Alle Erklärung muß fort, und nur Beschreibung an ihre Stelle treten" (\$109), ("All explanation must be done away with, and description alone must take its place" My translation). In this sense, "description" as Wittgenstein uses it may be understood as writing that seeks not to explain or fulfill a function but for itself to enact a kind of creation of its own, as a form for adding to the defining or establishing of things in the world (including itself) in a seemingly superficial or incidental manner. Explanation, on the other hand, is the attempt to get to the heart of things as though an elaborate uncovering were taking place in the words -something that Wittgenstein considers impossible. Description, however, implies the presence of a logical foundation from which to build and the lack of a sense of words as revelatory.

Beckett perfects this Wittgensteinian effect in the theatre where he is suddenly able to bring the audience closer to the dialogue so that, curiously, a more profound certainty, and subsequent estrangement, occurs. The narrator of Mercier et Camier writes, for example: "Il recommençait à pleuvoir. Mais la pluie avait-elle jamais cessé ?" (36) (“The rain was beginning again. But had it ever ceased?" [18]). Again, later in the text, the question of rain in the story arises, such that the reader cannot be sure if it is really raining or not. Mercier says to Camier: "Il pleut ferme, à ce qu'il me semble. Tu es 
même tout mouillé" (120) ("It's coming down, if I am to believe my eyes. Can you not sense you're wet?" [60]). Slightly different levels of obscurity between the English and French, both place significance on the importance or utter unimportance of the details of setting. It seems necessary to point out the setting, but then its relevance is immediately questioned. It is generally unclear if rain is actually falling, but, more importantly, it unclear how meaningful such a detail might be. This technique prompts Beckett's reader ask him or herself: what is worth reporting, how reliable is the reporting and why is it significant? Strong consideration is placed on the characters' senses. Beckett suggests that Mercier can perhaps mistrust his eyes, but how could he rightly mistrust the sensation of rain upon his body? This passage leads back to the distinction, according to Wittgenstein, between the sayable (sagbar), the sensical, and what is only showable (zeigbar), the metaphysical, ethical and aesthetic.

Comparatively, stage directions of the theatre productions obviously allow the scene to be immediately evident to the viewer, even when they are few or perhaps even vague (leaving the precise discretion up to the director, actors, and so on, which consequently still provides the viewer with a full and actual image on stage). The first stage directions of Godot automatically indicate the physical setting: "Route à la campagne, avec arbre. Soir" (6) ("A country road. A tree. Evening" [11]). Since the viewer can literally see the scene, the Verfremungseffekt of the ensuing dialogue is ultimately more powerful, since the sensory expectation is greater, in terms of being able to enter the scene and, particularly, of the rapport between the characters (with the removal of narration). Alternatively, the ambiguity in the prose work must be left as a technique for keeping the knowledge away from the reader, instead of drawing him or her in as in the theatre performance, and shattering that access through the possible surprise interactions between the characters. In other words, the focus can be upon the specifics of the staging itself and not simply on not knowing if the details reside in the prose or in the setting in which it is embedded.

An even more obvious example of this effect occurs toward the end of Mercier et Camier where the exchange involves an apparent (yet not evident) change of tone in the characters' exchange:

Tu ne sais pas où nous allons? dit Camier.

Qu'est-ce que ça peut nous faire, dit Mercier, où nous allons? Nous allons, c'est

suffisant.

Ne crie pas, dit Camier. (150-151)

Do you know where we are going? said Camier.

What does it matter, said Mercier, where we are going? We are going, that's enough.

No need to shout, said Camier. (73)

The reader must both believe Camier, that Mercier is shouting, but must also believe nothing, insofar as it is evident at this point in the novel that nothing is what it seems and that the characters' dialogues are not only rather meaningless but are generally misleading and unreliable. Beckett establishes and maintains this same Verfremdungseffekt in the theatre by creating a stage setting that inhibits the viewer from entering into the space of the world of the piece despite the enticing and obvious encouragement of the nature of the theatre itself. For example, the setting for Happy Days, written first in English, (1961, Oh les beaux jours 1962), includes the following: "Very pompier trompe-l'œil backcloth to represent unbroken plain and sky receding to meet in far distance" (138). In a letter to Alan Schneider in 1961, Beckett explains that 
he wanted this image to represent "a pathetic unsuccessful realism, the kind of tawdriness you get in a 3rd rate musical or pantomime, that quality of pompier, laughably earnest bad imitation" (94). Beckett creates a confounding sense of irony: the scene gives off an air of failure, of the inability to depict the scene realistically, through its unexpected presentation of everyday life under incredibly affected circumstances. Yet of course this effect is deliberate, and in its so-called failure, the scene precisely commands its own "bad imitation". This imitation continues to confound the audience, by both drawing them in with the everyday qualities but estranging them through the peculiarity of the specific "tawdriness" of the elements of the staging.

Similarly, writing of the effects of Beckett's plays, Blanchot says in L'Entretien infini (1969, The Infinite Conversation 1993): "Il faut renoncer au domaine du visible et de l'invisible, à ce qui se représente, fût-ce négativement. Entendre, seulement entendre" (482). ("One must renounce the domain of the visible and of the invisible, renounce what is represented, albeit in negative fashion. Hear, simply hear" (329)). The multiplicity within the concept "entendre" points both toward the curious state of hearing silence and toward literal and figurative senses of hearing, which in turn reconfirm the significance of the theatre as the literal space where entendre can be expressed more directly (and even visually). Figuratively, the visible can no longer stand for a projection of reality in Beckett. At the same time, the visible can be nothing other than representation precisely because it is literally appearance. For this reason, Beckett's appeal to the invisible-to what is possible beyond appearances-becomes a play with the senses. For, if the scene on stage simultaneously means both more and less than its overt depiction (more insofar as it demonstrates that it is not restricted to a representational meaning precisely through it's being less than expected, less than realistic), the viewer must rely on the other senses to do the explaining and find an understanding. More precisely, if Beckett asks his viewer to disallow any standard meaning of the image on stage, it becomes, as Blanchot says, a matter of sound instead of sight.

Silence, then, can take on a new significance by becoming a powerful indicator of an action taking place in contradistinction to what is not taking place (speaking, communicating and so on). For example, the inserted stage directions and director's notes of "silence" in Godot exemplify the weight of schweigen that is more possible in theatre than prose. Toward the end of Act I, Pozzo behaves as though he is engaged in an exchange with Estragon and Vladimir but which is more of a nonsensical monologue, where he suddenly asks (though no one has spoken): "Vous dites? (Silence.) Peut-être n'avez-vous rien dit? (Silence.) C'est sans importance" (37-38). ("I beg your pardon? (Silence.) Perhaps you didn't speak? (Silence.) It's of no importance" [29].) Beckett uses the theatre to provide a visceral space that noticeably marks the absurdity of asking questions in silence or, perhaps, of indifferently receiving no answers but only silence. The difference is in the performance of Godot, such that silence is made evident through its very presence and not simply through the reading of its existence. The viewer literally encounters the silence.

In the general stylistic shift from the form of Mercier et Camier as a novel to the theatre of Godot, performance as non-performance already becomes central, announcing specifically that the piece no longer tells the story, but rather the story can only ever insufficiently be told. A parallel can easily be drawn between the two works and the two sets of characters that allows a comparison between prose and script to be more 
readily and carefully observed. This exercise leads to a recognition of the efforts of both works to achieve silence and "nothing", while also indicating the greater success of Godot at this endeavor. The well-known critique of Godot in 1956 by Vivian Mercier elucidates:

Its author has achieved a theoretical impossibility-a play in which nothing happens, that yet keeps audiences glued to their seats. What's more, since the second act is a subtly different reprise of the first, he has written a play in which nothing happens, twice. ("The Uneventful Event" 95)

The key to this shift toward "nothing" as performed in the theatre rests in Beckett's interest in showing, as evidently as possible (thus, indicating the already fundamental necessity of the transformation from prose to theatre) not necessarily a nihilistic view of the world but the paradoxical nature of existence within language, which can only be made evident by means of the very deliberate and visual absence of ordinary action and in the empty space of vigorous, active silence.

In "Peintres de l'Empêchement" (1948), Beckett wonders: "Car que reste-t-il de représentable si l'essence de l'objet est de se dérober à la représentation ?" (136). (For, what is it that remains representable if the essence of the object is to evade representation? My translation.) He then also provides the answer: "Il reste à représenter les conditions de cette dérobade" (136). ("The conditions of this evasion remain to be represented" My translation.) Using prose as his first means to confirm his ontological response, Beckett attempts to establish an existential space between the text and the reader in Mercier et Camier-indeed, the question of writing and representation itself lay dormant in the text, which preceded the above-mentioned essay by several years. Dissatisfied, however, and perhaps uncertain, Beckett left the manuscript unpublished and moved on to the trilogy where he hoped to engage his response more effectively. Yet, not until Beckett began to write theatre would he be fully capable of developing a satisfactory illustration of his response to that nagging impossibility of a dérobade. The theatre permits Beckett to bring the reader-that is to say, now the viewer or the audience-into the space of the performance, which, for Beckett, becomes the space of non-action, of "nothing". In this way, Beckett attempts to get closer to the limits of language.

In the section entitled "La voix narrative" ("The Narrative Voice") from L'Entretien infini, Blanchot writes that the narrative voice exists as though in a sort of background, and it is this "in back" (380) ("en arrière" 557) that can serve as the space for the seemingly impossible distance that language needs in order to demonstrate its limit. Blanchot writes: "Se tenir dans le langage, c'est toujours déjà être au dehors" (557). ("To hold oneself in language is to be always already outside" [380].) However, language itself already forces the so-called limit to be unlimited by the limitless quality that is language itself. He begins this chapter with a metaphor that immediately recalls Beckett and his "literature of the unword": "On fait quelques pas dans la rue, on en fait huit ou neuf, puis l'on tombe. La limite qu'indique la fatigue limite la vie" (556). ("You take a few steps on the street, eight or nine, then you fall. The limit set by weariness limits life" [379].) As though a simultaneously direct and indirect reference to Beckett, Blanchot suggests that not only is language insufficient for "explanation" (as Wittgenstein would say), but that insufficiency actually limits, most literally, physical life as well. It sets Beckett's stage into states of absurdity, where movement itself is called into question-where all action and meaning is completely undermined and stripped down to silence. 
Blanchot then adds to this Beckettian image the following claim: "Le langage modifie la situation" (556). ("Language modifies the situation" [379].) This is because, of course, language inhibits but also permits expression. It creates the impossible by providing a system that can never fulfill its promise of wholly explaining its own existence or anything else. Blanchot writes: "La phrase que je prononce tend à attirer à l'intérieur même de la vie la limite qui ne devrait la marquer que de l'extérieur" (556). ("The sentence I pronounce tends to draw into the very inside of life the limit that was only supposed to mark it from the outside" [379].) Language draws back into life the limit that life seemed to be expressing; it unlimits the very limit that it establishes.

Widespread throughout Blanchot's work (Faux pas 1943, L'Espace littéraire 1955), this idea is also found readily enough across Beckett's entire oeuvre as well (e.g., Murphy 1938, the trilogy and Godot) and is also then taken further by both figures. Significantly, it is this philosophical next step that Beckett employs in his later work that reflects a phenomenological shift in his approach to getting at the unword in his languagecentered text-both in prose and theatrical form. What the next step entails is recognizing the space between the writing and the reader. In L'Entretien infini Blanchot says : "Ecrire c'est passer du 'je' au 'il'" (558). ("To write is to pass from 'I' to 'he'" [380].) It is this transference of the writer into the narrator at the moment of writing that signifies one of the greatest breakthroughs in Beckett's work as begun in Mercier et Camier and most fully expressed in Godot. At the moment of writing, the words are suddenly no longer pre-text ideas, or even pre-text words belonging to the writer, but they have become part of the world, part of the system of language and hence part of the immediate fictional text, perpetually beyond the writer and out of reach of any complete meaning.

3 Beckett affinities with Wittgenstein and Blanchot extend toward their perception of the use and limitations of language, using shared philosophical concepts to effect in his work, with the chapter summaries of Mercier et Camier serving as a notable example. Such pronouncements defy literary expectations by pointing not away from the text toward interpretative meaning but toward themselves as somehow unavailable to such analysis. reportage of nonsense and of the gaps in language, and for this reason he turns to the theatre for a fuller means for expression.

As shown with Mercier et Camier, Beckett begins his writing career intent on approaching and expressing the fallible nature of the text and of language, and, because he ultimately wants to strip even the language quality out of language, he moves toward theatre and creates Godot and other works that struggle to extract silence out of language. Yet, Beckett of course cannot strip out language at any cost, because it is already and only through language that the limits of language are expressed. The effort becomes one, then, of perpetually searching for the invisible silence that does not exist in words. The making of silence that permeates Beckett's work will always necessarily still be about the text, even in the text of the theatre. For Blanchot, this paradoxical effort in language that is transmitted in Beckett's works exemplifies the perpetual pursuit of the ephemeral concept of the sound of silence, focusing on the "sound" component-on the production, on the audience, namely on entendre. For Wittgenstein, Beckett's unknowing critic, this search takes the form of schweigen, focusing on the "silence" component-on the strangeness of speech to illustrate silence. Indeed, it is both the listening to and speaking about silence that makes Beckett's work rich, playful and unceasingly enigmatic. 


\section{BIBLIOGRAPHY}

Astbury, Helen. "Mercier et/and Camier : Un voyage de découverte linguistique est-il traduisible ? " Samuel Beckett Today/Aujourd'hui: Presence of Samuel Beckett/Présence de Samuel Beckett: Colloque de Cerisy 7 (1994): 109-120.

Atlas, James. "The Prose of Samuel Beckett: Notes from the Terminal Ward." Two Decades of Irish Writing: A Critical Survey. Chester Springs: Dufour Editions, 1975.

---. The Complete Dramatic Works. London: Faber and Faber, 1990.

---. "Dante ... Bruno. Vico ... Joyce." Our Exagmination Round His Factification for Incamination of Work in Progress. New York: New Directions, 1972

---. Disjecta: Miscellaneous Writings and a Dramatic Fragment. London : Calder, 1983.

---. Dossier de presse : En attendant Godot (1952-1961). Ed. André Derval. Paris : IMEC et Editions, 2007.

---. En attendant Godot. Paris : Minuit, 1952.

---. Happy Days. New York: Grove Press, 1961

---. Krapp's Last Tape and Embers. London: Faber and Faber, 1959.

---. The Letters of Samuel Beckett 1929-1940. Ed. Martha Dow Fehsenfeld and Lois More Overbeck. Cambridge and New York: Cambridge University Press, 2009.

---. “Letter to Schneider, 17 August 1961". Ed. M. Harmon. No Author Better Served: The Correspondence of Samuel Beckett \& Alan Schneider. Cambridge: Harvard University Press, 1998.

---. L'Innommable. Paris: Editions de Minuit, 1953.

---. Malone meurt. Paris: Editions de Minuit, 1951.

---. Mercier and Camier. Trans. Samuel Beckett. New York: Faber and Faber, 2010.

---. Mercier et Camier. Paris : Editions de Minuit, 2006.

---. Molloy. Paris : Editions de Minuit, 1951.

---. “Peintres de l'Empêchement.” Disjecta. London : Calder, 1983.

---. Waiting for Godot. The Complete Dramatic Works. London: Faber and Faber, 2006.

---. Watt. London : Calder, 1976.

Blanchot, Maurice. L'Entretien infini. Paris: Gallimard, 1969.

---. The Infinite Conversation. Trans. Susan Hanson. Minneapolis: University of Minnesota Press, 1993.

Cioran, E. M. “E. M. Cioran in 'Partisan Review’ (XLIII, 2, 1976, 280-5).” Samuel Beckett: The Critical Heritage. New York: Routledge, 2005.

---. Cinéma I: L'image-mouvement. Paris: Gallimard, 1983.

---. Cinema 1: The Movement-Image. Trans. Hugh Tomlinson and Barbara Habberjam. The Athlone Press: New York, 1986. 
Gaffney, Phyllis. "Normandy Landing." Beckett Centenary. 29 October 2010. <http:// www.irishtimes.com/focus/beckett/p6bott.htm>

Hoefer, Jacqueline (1959). “Watt.” Perspective 11: 166-82.

Kenner, Hugh. A Reader's Guide to Samuel Beckett. London: Thames and Hudson: 1973.

Knowlson, James. Damned to Fame: The Life of Samuel Beckett. New York: Simon and Schuster, 1996.

Mercier, Vivan. “The Uneventful Event.” The Critical Response to Samuel Beckett. Ed. Cathleen

Culotta Andonian. Westport, CT: Greenwood Press, 1998.

Perloff, Marjorie. Wittgenstein's Ladder. Chicago: University of Chicago Press, 1996.

Willits, Curt G. "The Blanchot/Beckett Correspondence: Situating the Writer/Writing at the Limen of Naught". In Colloquy text theory critique 10 (2005).

Wittgenstein, Ludwig. Philosophical Investigations / Philosophische Untersuchungen, bilingual ed., trans. G. E. M. Anscombe. New York: Macmillan, 1953.

---. On Certainty/Über Gewissheit. Trans. Denis Paul and G.E.M. Anscombe. Oxford: Blackwell, 1975.

---. Tractatus Logico-Philosophicus. Side-by-Side Edition, Version 0.23. Trans. C. K. Ogden, Frank

Ramsey, David Pears and Brian McGuinness. London: Kegan Paul [1922], 2010.

Worton, Michael. "Waiting for Godot and Endgame: theatre as text". The Cambridge Companion to

Beckett. Ed. John Pilling. Cambridge, New York and Melbourne: Cambridge University Press, 1994.

\section{ABSTRACTS}

Beckett's first major work in French, Mercier et Camier, written in 1946 but not published until 1974, in many ways foreshadows En attendant Godot (1953) and includes stylistic elements later found in the trilogy (Molloy 1951, Malone meurt 1951, L'innommable 1953). Mercier et Camier represents Beckett's first radical encounter with nihilism and absurdity in relation, specifically, to language play in a Wittgensteinian and Blanchotian sense. In this stylistic shift from the form of Mercier et Camier as a novel to the theatre of En attendant Godot, performance as nonperformance becomes central, announcing that the spectacle no longer tells the story, but, rather, the story can only ever insufficiently be told. This article focuses on the significance of silence and language in Beckett's transition toward the theatre, paying specific attention to possible intertextual relations with Wittgenstein and Blanchot and the significant overlap between their work concerning the impossible role of language and writing the self.

Le premier roman propre de Beckett en français, Mercier et Camier (écrit en 1946 mais publié en 1974) préfigure d'une certaine manière En attendant Godot (1953) et comporte des éléments du style trouvés plus tard dans la trilogie (Molloy 1951, Malone meurt 1951, L'innommable 1953). Mercier et Camier représente la première rencontre radicale de Beckett avec le nihilisme en rapport, spécifiquement, avec le jeu du langage dans un sens de Wittgenstein et Blanchot. Dans son changement stylistique de la forme de Mercier et Camier comme roman au théâtre d'En attendant Godot, le concept de la représentation comme non-représentation devient central, annonçant que le spectacle ne dit plus l'histoire, mais plutôt que l'histoire ne peut qu'être insuffisamment racontée. Cet article se concentre sur l'importance du silence et du langage dans la transition de Beckett au théâtre, en prêtant une grande attention aux relations intertextuelles possibles avec Wittgenstein et Blanchot et le lien considérable entre leurs œuvres, concernant le rôle impossible du langage et l'écriture de soi. 
INDEX

Keywords: philosophy and literature, language games, literary criticism, modern literature, 20th century literature, 20th century theatre, literature in French, translation

Mots-clés: philosophie et littérature, jeux de langue, critique littéraire, littérature moderne, littérature du xxe siècle, théâtre du xxe siècle, littérature en français, traduction

\section{AUTHORS}

KATY MASUGA

PhD

University of Paris-III : La Sorbonne

Nouvelle 